\title{
MARKETING AS A PROBLEM FOR FARM DEMONSTRATORS.
}

\author{
B. H. Hibbard, \\ University of Wisconsin, Madison.
}

Clearly marketing is one of the most difficult problems conf ronting the farmer. It will continue to be difficult for years to come, and in all probability will never be entirely settled. One explanation of the difficulty is the fact of the human relationships involved. When any worker on the production side of agriculture goes out to fight for humanity against the leaf hoppers or the San Jose scale, he is cheered on the occasion of every success and encouraged in every effort. All society is against the San Jose scale. In the marketing world the offenders are human beings, with the same rights as the rest of us. It may happen that the supposed offenders are as efficient and honest as the people who criticize them. Even so, the system in which they are involved may need change. It may be imperative that a change be made, and the very fact of a change may hurt certain individuals. These individuals and their friends will not welcome the innovation. During these times of high prices the middleman comes in for a new scrutiny. His margins are the subject of suspicion. The justification of his very existence in the capacity of a merchant is questioned. The concern of those interested in marketing is whether the marketing machinery is reasonably well adapted to the work it has to do, and the manner in which it operates.

We might take up much time with the history of marketing, but it will be necessary to pass over this very interesting phase of the subject with a few words. The marketing problem is new because it is but a relatively short time back to the self-sufficing farm and the neighborhood when farm produce, with few exceptions, was able to make its way into the national and world markets. For years after farmers were producing for the great markets they were completely out of touch with the forces governing such markets.

Following the Civil War the center of production moved toward the west more rapidly than the center of population. Within a few years production outgrew its markets. Corn was worth five to twenty cents a bushel, oats about the same, and wheat fell below a half dollar Jocally in many districts. Transportation systems were new and badly planned from the standpoint of economy, with the result that 
freight rates were high. For example, it cost, during the early 7o's, four fifths of the New York price of grain to carry the grain from Iowa to the seaboard.

These facts account in large measure for the farmer movement that culminated in the Grange. The farmers were convinced that the railroads were to blame for the situation. The whole marketing question involving processes and agencies came to the front as never before. The middlemen as well as the railroads were involved in the program, and during the years 1870 to $I 880$ the problems of marketing occupied the center of the stage. With certain periods of quiescence we have had a marketing campaign in progress in some part of the field from that day to this. This morning's paper announces that there is destined to be a revolution in marketing methods.

The first thing for the farmers to do in connection with any marketing innovation is, where possible, to discover the facts. Very frequently the real facts are quite different from the imagined facts. Within the past few years studies have been made in connection with the marketing of several leading farm products.

It is easy for a clever speaker by innuendo to get applause from an audience on such a subject as the relation of the packer to the farmer. In a talk of this kind, not a single fact is, as a rule, employed. Or if facts are used, they are distorted or taken out of their proper setting. What we need on the packer question, as on others, is a true and faithful setting forth of the situation as it really is. The time is past when the packers can afford to withhold the necessary information for a story of their work. Criticism has gone too far, and public sentiment been too much stirred for them longer to gain by assuming that their affairs are nobody's business but their own.

One thing that every farm demonstrator should understand clearly is that in most marketing operations the greater opportunities for loss or gain are more likely to be near to the farmers' door than in a distant market. This is no effort to apologize for or cover up crookedness in the central markets. However, the opportunity nearest at hand should occupy the attention first. A good instance was reported from Nebraska last year. A farmer with two fat cows to sell asked the local buyer how much he would give for them. The reply was "Six cents a pound, or \$140." By slow degrees the buyer came up to eight cents or a lump sum of $\$ 175$. The farmer refused and sent them to Omaha through a livestock shipping association, and received for the two head $\$ 113$ more than the first offer by the local buyer. This is no doubt an extreme instance, but there are numberless instances of purchase of stock from farmers at prices so low as to give 
the buyer at the home station a margin many times greater than that taken by the packers. It does not follow that these local buyers get too wealthy. The competition for the business is such that, one time with another, the returns are not high enough to make a great income. However, this does not insure a fair price to the farmer, since the margin of doing business under these circumstances is altogether too wide.

Livestock Shipping Associations Succeed.-In a certain Wisconsin village three stock buyers were buying stock and three families were getting a living out of it. They used to drive horses, later they had to have automobiles. Farmers got together one time because of a little dissatisfaction. Somebody did not get what his produce was worth so he started a movement. He said, "Let us ship our own stock." They held a meeting, got over a hundred members to join, and one man working two days does all the work for that entire community and does the work of all the association. They pay him for two days' work. He does in one third the time what three men did on full time. These other three men are making a living at something else. They do not like to be put out of business. We do not like to see them put out. They were going ahead in a natural way; they were not getting rich, but they were not doing the work economically. We are going to be asked questions as to whether or not we should do this.

Now, here is a question that came to me. A county agent writes in and says they have twenty-four creameries in their county. They have recently held a meeting. They are not satisfied with market conditions and they propose to build a cold storage house in order to hold their butter over until winter months when butter will be higher priced. What do you think about it? Can twenty-four creameries do it? It is hard to say. In any case, whenever you give farmers advice on marketing, this one thing you want to be careful about. Either advise them not to go into a speculating business or advise them to go in knowing what it is like, so they may have their eyes open. All storage is a speculative arrangement, and what is there always cheap in the fall and dear in the spring? Do you know that if you had all your money tied up in wheat every September and made all your sales the following May you would have a good many nervous moments between those two dates and a great many years you would not come out with a big bank account to your credit because the price of wheat in May is not much more than in September beyond carrying costs. Now, shall these people put their butter in cold storage in June, July and August for sale in February, March 
and April? If they do they are going to assume the risks of the speculator. The ups and downs of speculation are well shown in the occurrences in the cheese market a few years ago. During the first year of the Wisconsin Cheese Federation they had this story going around: One certain cheese dealer, speculating in cheese, sometimes selling five minutes and sometimes five months after buying, paid $\$ 853$ in income tax one year. It is a very big sum to pay in income taxes and suggests a pretty big income from one year's business. So they said: "That is our money." This particular man did pay $\$ 853$ income tax one year but the next year he didn't pay any. He had handled cheese and the price did not go up beyond carrying cost so he made no money and the State got nothing in the way of income tax; the next year he was bankrupt, and the next year he died. His friends said he died because of business worries and yet this is the particular man who was held up to ridicule because he was stealing from farmers. One year the farmers were all anxious to speculate; the next year the price failed to rise and they were glad they had not speculated. If the farmers go into the speculating business, there is one thing that is surely going to happen; they are going to lose sometimes by the speculation and just as surely as they do the losses are going to impress them more than the gains. There isn't a very great deal of coöperation in betting. If you want to bet on a horse or a baseball game, you don't usually hunt up several people to help share the bet. The rest would say that it was not their judgment that was followed if you lose. The same is true of farmers. If farmers speculate in butter the verdict will be: "It was not my judgment to hold this butter, but we had a poor manager." When it goes up they will take their checks as a matter of course and not even know how much of it was due to the shrewdness of the manager. They do not know that they have gained by speculation, but they will be very keen as to losses, and they will remember the loss for a long time after the gains are forgotten. It is where the evil that men do lives after them. If they go into genuine speculation there is going to be trouble ahead.

The fact of greater savings near home is shown in the marketing of grain. The best grain marketing organization among the grain growers is not found in the United States. It is in Canada. They have beaten us very much in the way of organizing their own grain business. They started out about the same time we did to make some headway in the grain market as farmers. They have gone on steadily, quietly, safely, toward what seems to be the best grain marketing association we have in America. One of the leaders of that organization about three years ago, during the war, made this unqualified 
statement: "We started out because of our antipathy against the grain gamblers and we were going to see why those gentlemen should drag the price of grain up and down at will. We began locally, then effected a central organization." They werc after the grain gamblers of Winnipeg. They organized their central office at headquarters. They brought the grain in from the country and then again they organized a subsidiary company and carried it across the Atlantic, not to one port but to a dozen, and they have been for sone years marketing grain in Italy, France, England, Belgium, and Germany. They have gone to practically all the ports of Europe with their own wheat. After they have risen to the point where they can get a bird's-eye view of the farmers' production, the millers' operations and the wholesale market of Europe, they should be able to answer this simple question: "Where did you find the great advantage of this system over the regular commercial system?" It was mostly at the home elevator. That is where they found the big margin. They did not go out and attack anybody. They simply said, "There is a way to get grain to the world at less expense." They quietly went ahead and built their own elevator and the others had to get out of the way or get into it at some other place.

That the great margins are near home is not because any particular one is to blame for it. Competition carries us so far and no farther. If four of us had each an elevator at a given point, and if we had no other means of support, and circumstances were such that we had to get a living out of it, we would show our books and say we couldn't handle grain at a smaller margin than the one prevailing. We arrange our business in accord with what it takes for us to live on. Therefore, there is competition; and competition means high prices as much as it means low prices. Here comes the farmer group. There are perhaps 160 grain growers in this group. Most of them have been patronizing the four elevators. Let us say something like 6 cents has been required to put grain through the elevator. The group can do it for about 3 cents if they have one big elevator under one man. The farmers by getting together leave these men in the lurch. We may be sorry for them, but we can't keep on supporting them. The whole group will put this grain through the elevator at 3 cents mainly because of the advantage of big business.

A most excellent example of what farmers can do in conquering a market is that of the Wisconsin Cheese Producers' Federation, referred to above. It now has a history of nearly seven successful years. In the beginning it was believed by the farmers that a considerable part of the wide margin between what the farmer received and 
what the consumer paid was graft, or waste. A careful study showed that by far the greater part of the spread was necessary under present management. The Federation can save enough to justify the effort, but it can not close up the major part of the wide gap.

The best results of the marketing studies and marketing plans thus far is the information which has been brought to light. It is futile and fatal to rail against monsters of the imagination. The thing to do is to find out what the case in question really is, and then prescribe a remedy which fits the case. Information is not always readily available, but action without it is worse than useless.

\section{NEWS NOTES.}

Mr. M. O. Pence, county agent leader in Delaware, will also act as farm managenent demonstrator in this State.

Mr. Ben Eldredge, a graduate of the Utah Agricultural College and for many years a successful dairyman, has been appointed as farm nianagement demonstrator in Utah. More recently Mr. Eldredge has been employed in dairy extension work in Utah.

Mr. Stanley F. Morse of New Orleans was recently elected president of the southern section of the American Society of Agricultural Engineers, at the annual convention of this association, which was held at Memphis, Tennessee, during the latter part of August.

Mr. A. B. Cox succeeds Mr. H. M. Eliot as chief in farm and ranch economics in the Texas Experiment Station at College Station, Texas.

Mr. J. S. Ball, assistant in farm accounting in the Office of Farm Management and Farm Economics, Washington, D. C., has resigned and has accepted a position with the American Audit Company, Colorado Building, Washington, D. C.

Mr. H. R. Tolley, who has been with the Office of Farm Management and Farm Economics for several years, has been transferred to the Division of Rural Engineering, Bureau of Public Roads, Washington, D. C.

Prof. Frank App, of the New Jersey Experiment Station, has changed his duties somewhat this autumn. He writes as follows: "I am taking temporary leave from the work at New Brunswick to serve as secretary of the State Council of County Boards of Agriculture in New Jersey. This does not mean that I am completely separating myself from investigational work in the state. I hope to continue in close touch as I have in the past. However, it will prevent my doing any teaching." 